\title{
Assessment of hand hygiene of nursing and medical students
}

\author{
Avaliação da higienização das mãos de acadêmicos de Enfermagem e Medicina
}

Vanessa Dias da Silva ${ }^{1}$, Joselany Áfio Caetano ${ }^{2}$, Leonardo Alexandrino da Silva ${ }^{2}$, Marta Maria Costa Freitas ${ }^{4}$, Paulo César de Almeida ${ }^{3}$, Jorge Luís Nobre Rodrigues ${ }^{4}$

Objective: to verify the ability of nursing and medical academics related to hand hygiene technique. Methods: this is a cross-sectional study carried out with 61 academics. Hands hygiene with $70.0 \%$ alcohol gel was used, in which Visirub® fluorescent dye was added, which allowed observing areas not contemplated during hand hygiene and investigation of the eight steps recommended by the World Health Organization. Results: $35.7 \%$ of nursing academics and $15.1 \%$ of medical students used the hand hygiene technique with $70.0 \%$ alcohol gel following the eight recommended steps. The least accomplished steps by the nursing academics were "rubbing the back of each hand with the back of the other", as $46.4 \%$ did not perform it. Among medicine students, the least accomplished step was "rubbing the back of the fingers with the palm of the other hand", by 63.6\%. No scholar was able to contemplate all areas. Conclusion: no academic has been able to perform hand hygiene in all areas properly, hence the need to reinforce the correct technique.

Descriptors: Hand Disinfection; Infection Control; Students, Nursing; Students, Medical.

Objetivo: verificar a habilidade de acadêmicos de enfermagem e medicina relacionados à técnica da higienização das mãos. Métodos: estudo transversal realizado com 61 acadêmicos. Utilizou-se a higienização das mãos com álcool gel a 70,0\%, no qual foi adicionado o corante fluorescente Visirub ${ }^{\circledR}$, que permitiu observar áreas não contempladas durante a higienização das mãos e investigação dos oito passos recomendados pela Organização Mundial de Saúde. Resultados: 35,7\% dos acadêmicos de enfermagem e 15,1\% dos acadêmicos de medicina empregaram a técnica de higienização das mãos com álcool gel a 70,0\% seguindo os oito passos recomendados. Os passos menos realizados pelos acadêmicos de enfermagem foram "esfregar palma com dorso", 46,4\% não realizaram, e de medicina "esfregar costas dos dedos sobre as palmas", 63,6\%. Nenhum acadêmico conseguiu contemplar todas as áreas. Conclusão: nenhum acadêmico conseguiu realizar a higiene das mãos em todas as áreas adequadamente; daí a necessidade de reforçar a técnica correta.

Descritores: Lavagem das Mãos; Controle de Infecções; Estudantes de Enfermagem; Estudantes de Medicina.

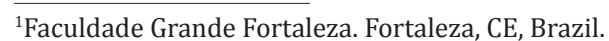

${ }^{2}$ Universidade Federal do Ceará. Fortaleza, CE, Brazil.

${ }^{3}$ Universidade Estadual do Ceará. Fortaleza, CE, Brazil.

${ }^{4}$ Hospital Universitário Walter Cantídio. Fortaleza, CE, Brazil.

Corresponding author: Joselany Áfio Caetano

Rua Aécio Cabral, 300, Casa 400. Dionísio Torres. CEP: 60135-480. Fortaleza, CE, Brazil. E-mail: joselany@ufc.br
} 


\section{Introduction}

Hands are body structures widely used in direct contact with the patient, and are the main means of transmission of microorganisms. Thus, non-adherence to hand hygiene impairs the quality and safety of care provided ${ }^{(1)}$. Studies have reinforced the importance of the hands of health professionals as a source of dissemination of microorganisms that cause infections ${ }^{(2)}$.

In order to break this chain of transmission, basic hygiene standards must be adopted in the hospital environment, of which hands hygiene has the greatest impact. Hand hygiene covers the processes of simple hygiene, antiseptic cleaning, antiseptic friction and surgical antisepsis of the hands, and this method is used according to the need or action to be performed with the patient ${ }^{(3)}$. Thus, some moments are recommended for hand hygiene: before and after contact with the patient, before the aseptic procedure, after exposure to body fluids, and after contact with areas close to the patient ${ }^{(4)}$.

Despite the dissemination of information about the need for hand hygiene, this practice still has not had the necessary adherence by health professionals. This fact may be related to the lack of equipment, products and supplies needed to perform this procedure ${ }^{(5)}$.

Knowledge of hand hygiene as a measure to prevent health care-related infections comes from ancient times, but for many reasons it has been neglected by many health professionals. Studies have so far shown the importance of assessing practitioners' knowledge, risks, attitudes and perceptions for hand hygiene as a means of designing healthcare-related infection prevention programs associated with any level of care ${ }^{(6-8)}$. In this context, adequate training both in undergraduate course ${ }^{(9)}$ and in professional practi$\mathrm{ce}^{(10-11)}$ through specific training interventions is also as an effective means of intervention.

Among the reasons for neglect by many professionals, there are the overload of work due to the insufficient number of human resources; lack of available sinks or alcohol gel dispensers, or inadequate location of these; lack of liquid soap, paper towels and alcohol gel; and lack of knowledge about the effectiveness of this measure, among other reasons ${ }^{(9)}$.

Given the importance of the hands in the care provided to the patient and that adequate hands hygiene contributes significantly to the prevention and control of health-care-related infections and, taking into account that this practice should be used routinely, an initial phase of the diagnosis on the hand hygiene technique of medical and nursing academics must be carried out $t^{(9,12-15)}$. Thus, a question arises: what is the ability of nursing and medical academics in relation to the practice of hand hygiene?

This theme is relevant not only to encourage adherence to the practice but also to observe if its execution is being performed correctly, since providing instruction on this content is an alternative to adopt a safer care for the patient and for the health servi$\mathrm{ce}^{(9,16)}$. The results of this study will help to delimit the needs regarding the teaching of the technique, so that the students leave the undergraduate course able to execute their activities using the most effective method to minimize the infections related to health care. In view of the above, the present study aimed to verify the ability of nursing and medical academics related to the practice of hand hygiene.

\section{Methods}

This is a cross-sectional study carried out at Federal Public University in Fortaleza, Ceará State, Brazil. The population was comprised of nursing students (6th and/or 7th semester) and medical academics (7th and/or 8th semester), in a federal public university in Fortaleza, Brazil, during the first semester of 2012. These semesters were chosen because they precede the internship period, so, at this time, students have already had theoretical-practical classes within the student curriculum, receiving knowledge about hand hygiene. Internship is a period composed of a supervised training; therefore, students need to 
have a good knowledge about hand hygiene. These periods had approximately 80 nursing academics and 160 medical students in undergraduate courses.

The inclusion criterion was being attending the 6th and/or 7th semester of nursing and the 7th and/ or 8th semester of medicine. The exclusion criterion was not being formally enrolled in the disciplines of these semesters.

Data collection took place after contacting the teachers of the disciplines of these semesters to present the objectives of the research and request authorization for data collection in their classes. After the teachers' authorization, in the classroom for their class, students were invited to participate in the study.

A sample calculation was performed based on the statistical formula for determining the sample size in cross-sectional studies, with a confidence level of 95.0\% (bicaudal test), $80.0 \%$ statistical power, relative risk of 0.05 . The sample consisted of 28 nursing students from the 6 th semester and of 33 medical students who attended the 7th semester.

Data were collected in March 2012 by a single observer to avoid bias in the observation, and the students were observed individually, being observed the hand hygiene technique that was performed with 70.0\% alcohol gel, in which dye was added Fluorescent (Visirub®, Bode Chemie Hamburg) ${ }^{(17)}$. The amount of alcohol gel volume used was not measured, so that the participants themselves used the quantity that they found satisfactory.

The assessment of the hand hygiene technique was carried out by means of direct observation of the friction of the hands with alcohol gel, for which the World Health Organization Handbook ${ }^{(16)}$ was used as reference. Assessment was also carried out through an educational tool, namely a pedagogical box that has a ultraviolet light at 26 watts, which allows the visualization of the covered areas during hand hygiene by the fluorescence of the dye added to $70.0 \%$ alcohol gel. Hand hygiene technique was observed accord- ing to the seven steps recommended by the World Health Organization, namely: removing adornments, rubbing palm to palm, rubbing the back of each hand with the palm of the other, rubbing interdigital spaces, rubbing the back of the fingers with the palm of the other hand, rotating each thumb over the palm of the other hand, rubbing the tips of the fingers with the palm of the other hand ${ }^{(16)}$. After observing the hygiene of the hands, students inserted their hands inside the pedagogical box that has an ultraviolet light bulb. The use of the box provided an environment of better visibility of areas affected by alcohol gel that, when exposed to ultraviolet light, became fluorescent; thus, the areas of the hands that did not have this characteristic were considered as neglected areas at the time of hand hygiene. Observation was recorded for the four main regions of both hands: palms, backs of hands, interdigital spaces and fingertips.

As an instrument for data collection, a structured observation script of the hand hygiene process was used, based on the World Health Organization Handbook $^{(16)}$, composed of two parts: the first one referring to the $70.0 \%$ alcohol gel rubbing hand hygiene technique added to the fluorescent dye ${ }^{(12)}$ and the second one referring to the areas whose hygiene was considered effective, as observed through the pedagogical box.

Collected data were statistically processed using the Statistical Package for the Social Sciences 20.0.0 software. A descriptive analysis of the data was performed; the chi-square test was used to measure the association of ability between nursing and medical academics, and a significance level was set at 5\%. Thereafter, data were discussed and supported in the relevant literature.

The study complied with the formal requirements contained in the national and international regulatory standards for research involving human beings. 


\section{Results}

The sample consisted of 61 students, of whom 28 were nursing students and 33 were medical students. Table 1 shows the distribution of students according to the course and the hand hygiene technique. Interestingly, only $35.7 \%$ of nursing students and $15.1 \%$ of medical students used the $70.0 \%$ alcohol gel hand hygiene technique following the seven steps recommended by the World Health Organization.

Table 1 - Distribution of academics according to the course and hand hygiene technique

\begin{tabular}{|c|c|c|c|c|c|}
\hline \multirow[b]{2}{*}{ Hand Hygiene Technique } & \multicolumn{2}{|c|}{ Nursing } & \multicolumn{2}{|c|}{ Medicine } & \multirow[b]{2}{*}{$\mathbf{p}^{*}$} \\
\hline & $\begin{array}{c}\text { Yes } \\
\mathbf{n}(\%)\end{array}$ & $\begin{array}{c}\text { No } \\
\text { n(\%) }\end{array}$ & $\begin{array}{c}\text { Yes } \\
\text { n(\%) }\end{array}$ & $\begin{array}{c}\text { No } \\
n(\%)\end{array}$ & \\
\hline Removing hand adornments & $15(53.6)$ & $13(46.4)$ & $16(48.5)$ & $17(51.5)$ & 0.692 \\
\hline Rubbing palm to palm & $26(92.9)$ & $2(27.1)$ & $33(100)$ & - & 0.118 \\
\hline $\begin{array}{l}\text { Rubbing the back of each hand } \\
\text { with the palm of the other }\end{array}$ & $15(53.6)$ & $13(46.4)$ & $24(72.7)$ & $9(27.3)$ & 0.121 \\
\hline Rubbing interdigital spaces & $27(96.4)$ & $1(3.6)$ & $25(75.8)$ & $8(24.2)$ & 0.023 \\
\hline $\begin{array}{l}\text { Rubbing the back of the } \\
\text { fingers with the palm of the } \\
\text { other hand }\end{array}$ & $22(78.6)$ & $6(21.4)$ & $12(36.4)$ & $21(63.6)$ & 0.001 \\
\hline $\begin{array}{l}\text { Rotating each thumb over the } \\
\text { palm of the other hand }\end{array}$ & $27(96.4)$ & $1(3.6)$ & $20(60.6)$ & $13(39.4)$ & 0.001 \\
\hline $\begin{array}{l}\text { Rubbing the tips of the fingers } \\
\text { with the palm of the other } \\
\text { hand }\end{array}$ & $24(85.7)$ & $4(14.3)$ & $18(54.5)$ & $15(45.5)$ & 0.009 \\
\hline
\end{tabular}

In order to sanitize hands, the first step to be followed is the removal of hand and forearm adornments, and $53.6 \%$ of nursing students and $48.5 \%$ of medical students performed this procedure (the non-removal of the adornments interferes with the quality of hand hygiene technique); as for rubbing palms with palms, $92.9 \%$ of nursing academics and $100.0 \%$ of medical students performed it; rubbing palm with back was performed by $53.6 \%$ of nursing students and by $72.7 \%$ of medical students. In these phases, there were no statistically significant differences between the groups.

Rubbing interdigital spaces was performed by $96.4 \%$ of nursing academics and $75.8 \%$ of medical academics; rubbing backs of the fingers with the palms was performed by $78.6 \%$ of nursing academics and $36.4 \%$ of medicine students; thumb rotation over the palm was performed by $96.4 \%$ of nursing academics and $60.6 \%$ of medicine academics; and rubbing the tips of the fingers and nails with the palms, by $85.7 \%$ of nursing academics and $54.5 \%$ of medicine students. In the aforementioned steps, there were statistically significant differences between the groups.

Table 2 shows the distribution of students according to the course and the areas sanitized by the hand hygiene technique. No academic was able to contemplate all the areas, that is, none was able to maintain the seven regions of the hands that are considered important to be analyzed for a proper hand hygiene adequately sanitized.

Table 2 - Distribution of academics according to the course and areas affected by hand hygiene

\begin{tabular}{lccccc}
\hline \multirow{2}{*}{$\begin{array}{l}\text { Areas affected by } \\
\text { hand hygiene }\end{array}$} & $\begin{array}{c}\text { Yes } \\
\mathbf{n}(\%)\end{array}$ & $\begin{array}{c}\text { No } \\
\mathbf{n}(\%)\end{array}$ & $\begin{array}{c}\text { Yes } \\
\mathbf{n}(\%)\end{array}$ & $\begin{array}{c}\text { No } \\
\mathbf{n}(\%)\end{array}$ & $\mathbf{p}^{*}$ \\
\hline Palms & $23(82.1)$ & $5(17.9)$ & $33(100)$ & - & 0.011 \\
Back & $4(14.3)$ & $24(85.7)$ & $7(21.2)$ & $26(78.8)$ & 0.483 \\
Interdigital spaces & $15(53.6)$ & $13(46.4)$ & $15(45.5)$ & $18(54.5)$ & 0.527 \\
Fingers & $18(64.3)$ & $10(35.7)$ & $15(45.5)$ & $18(54.5)$ & 0.023 \\
Thumb & $9(32.1)$ & $19(67.9)$ & $4(12.1)$ & $29(87.9)$ & 0.057 \\
Fingertips & $12(42.9)$ & $16(57.1)$ & $13(39.4)$ & $20(60.6)$ & 0.784 \\
Periungual regions & $17(60.7)$ & $11(39.3)$ & $8(24.2)$ & $25(75.8)$ & 0.004 \\
\hline *Statistical significance of test $X^{2}$ & & & &
\end{tabular}

The palms of the hands were correctly sanitized by $82.1 \%$ of the nursing students and $100.0 \%$ of the medicine students; the back, by $14.3 \%$ of the nursing students and $21.2 \%$ of medicine students; thumbs, by $32.1 \%$ of the nursing students and $12.1 \%$ of medicine students; fingertips, by $42.9 \%$ of the nursing students and $39.4 \%$ of medicine students. In these phases, there were no statistically significant differences between the groups. 


\section{Discussion}

In the present study, only $35.7 \%$ of nursing academics and $15.1 \%$ of medical students followed the seven steps recommended by the World Health Organization for the $70.0 \%$ alcohol gel hand washing technique. Study conducted in Hungary with 253 medical students ${ }^{(8)}$ found that $74.3 \%$ of the students were unable to perform the surgical hand hygiene technique correctly. Data from the present study on the hand hygiene technique show that nursing students had better performance of this skill when compared to medical students. Research comparing knowledge, beliefs and practices among nursing and medical students in Greece ${ }^{(15)}$ corroborates with the present study, since it pointed out that nursing students had more knowledge, beliefs and practices about hand hygiene than medical students, in addition to having received a higher frequency of guidance on this subject compared to medicine students. Despite having a course with longer duration in years, medical students obtained a lower theoretical approach on this subject.

The findings of the present study converge with data from research conducted with medical academics of the University of Debrecen ${ }^{(8)}$, in which the hand areas less affected by hands hygiene were the dorsal regions of the thumb and first metacarpal, as well as palm regions between the second and fifth metacarpals. Study carried out in a hospital in Spain ${ }^{(11)}$ investigated the quality of the hand hygiene technique performed by 133 physicians and 241 nurses. The results of this investigation showed that the thumbs were correctly sanitized by only 52 (39.1\%) nurses and 96 (39.8\%) physicians; and fingertips by only 63 (47.3\%) nurses and 124 (51.4\%) physicians.

Based on the findings related to the evaluation of the seven areas, the nursing and medical academics in six areas obtained a higher percentage of error, that is, of inadequate hand hygiene. This data evidences that nursing and medical academics finish the under- graduate level with a deficit of skill and knowledge on the correct hand hygiene technique ${ }^{(8,15,18-19)}$. This finding is worrisome since interventions that contemplate correct hand hygiene have been cited as important factors for the reduction of health care-related infections and improved professionals' knowledge of how to prevent them ${ }^{(20)}$.

Regarding the limitation of the study, the time used for hand hygiene by the academics was not observed, nor the teaching plan and/or content on hand hygiene covered in the disciplines was analyzed. This prevented the characterization of the content related to hand hygiene, addressed in the curriculum of both courses.

It is important to emphasize that among the factors that contribute to patient safety during their health care is hand hygiene, which is one of the goals of the World Health Organization to prevent infections. Also, when nursing and medical student graduate without performing this technique properly, they put at risk the care for users.

\section{Conclusion}

During the observation of the hand hygiene technique with $70.0 \%$ alcohol gel, the majority of the students performed the technique incorrectly, but when analyzing the technique step-by-step and the nursing and medical students were compared, a greater percentage of adequacy to the steps was perceived among nursing academics. This fact reinforces that the curriculum program of the nursing course may favor a greater approach on the correct hand hygiene technique when compared to the medical course.

In the observation of the affected areas through hand hygiene, no academic was able to reach all the areas properly. Most of the areas had an error rate greater than $50.0 \%$ : back of the hand; interdigital spaces; thumb; fingertips and periungual region. These findings contribute to the understanding of the risk that 
patients take due to the deficiency of professionals in sanitizing their hands, which leads to an increase in cases of health-care-related infections and the consequent increase of associated morbidity and mortality, since unsafe care has been provided for the patient in this issue, as cross infection is considered an avoidable adverse event.

\section{Collaborations}

Silva VD, Caetano JA, Silva LA, Freitas MMC, Almeida PC and Rodrigues JLN contributed to project design, data analysis, article writing, critical review of intellectual content and final approval of the version to be published.

\section{References}

1. Primo MGB, Ribeiro LCM, Figueiredo LFS, Sirico SCA, Souza MA. Adesão à prática de higienização das mãos por profissionais de saúde de um hospital universitário. Rev Eletr Enferm [Internet]. 2010 [citado 2016 out 20]; 12(2):266-71. Disponível em: https://www.fen.ufg.br/fen_revista/v12/n2/ v12n2a06.htm

2. Ho HJ, Poh BF, Choudhury S, Krishnan P, Ang B, Chow A. Alcohol hand rubbing and chlorhexidine handwashing are equally effective in removing methicillin-resistant Staphylococcus aureus from health care workers' hands: A randomized controlled trial. Am J Infect Control. 2015; 43(11):1246-8.

3. Ministério da Saúde (BR). Agência Nacional de Vigilância Sanitária. Segurança do paciente. Higienização das mãos. Brasília: Ministério da Saúde; 2008.

4. World Health Organization. WHO guidelines on hand hygiene in health care. First global patient safety challenge clean care is safer care. Geneva: WHO; 2009.
5. Abdella NM, Tefera MA, Eredie AE, Landers TF, Malefia YD, Alene KA. Hand hygiene compliance and associated factors among health care providers in Gondar University Hospital, Gondar, North West Ethiopia. BMC Public Health [Internet]. 2014 [cited 2017 jan 13];14(1):96. Available from:http://bmcpublichealth.biomedcentral. com/articles/10.1186/1471-2458-14-96

6. Pérez-Pérez $P$, Herrera-Usagre $M$, BuenoCavanillas A, Alonso-Humada MS, Buiza-Camacho B, Vázquez-Vázquez M. A higiene das mãos: as competências profissionais e as áreas de melhoria. Cad Saúde Pública. 2015; 31(1):149-60.

7. Alp E, Ozturk A, Guven M, Celik I, Doganay M, Voss A. Importance of structured training programs and good role models in hand hygiene in developing countries. J InfectPublic Health. 2011; 4(2):80-90.

8. Vanyolos E, Peto K, Viszlai A, Miko I, Furka I, Nemeth $\mathrm{N}$, et al. Usage of ultraviolet test method for monitoring the efficacy of surgical hand rub technique among medical students. J Surg Educ. 2015; 72(3):530-5.

9. Ferreira VTA, Santana SA, Martins MK, Silva SAC, Lima VSS. Técnica de higienização simples das mãos: a prática entre acadêmicos da enfermagem. Cienc Enferm. 2010; 16(1):49-58.

10. Lehotsky Á, Szilágyi L, Ferenci T, Kovács L, Pethes $\mathrm{R}$, Wéber $\mathrm{G}$, et al. Quantitative impact of direct, personal feedback on hand hygiene technique. J Hosp Infect. 2015; 91(1):81-4.

11. Škodová M, Urra FG, Benítez AG, Romano MR, Ortiz AG. Hand hygiene assessment in the workplace using a UV lamp. Am J Infect Control. 2015; 43(12):1360-2.

12. Yaembut N, Ampornaramveth RS, Pisarnturakit PP, Subbalekha K. Dental student hand hygiene decreased with increased clinical experience. J Surg Educ. 2016; 73(3):400-8.

13. Chacko LK. Knowledge of hand hygiene and its self reported practice among nursing students during clinical experience at a teaching hospital in Mangalore. J Patient Safety Infec Control. 2014; 2(2):55-7. 
14. Škodová M, Gimeno-Benítez A, Martínez-Redondo E, Morán-Cortés JF, Jiménez-Romano R, GimenoOrtiz A. Hand hygiene technique quality evaluation in nursing and medicine students of two academic courses. Rev Latino-Am Enfermagem. 2015; 23(4):708-17.

15. Nair SS, Hanumantappa R, Hiremath SG, Siraj MA, Raghunath P. Knowledge, attitude, and practice of hand hygiene among Medical and Nursing students at a Tertiary Health Care Centre in Raichur, India. ISRN Prevent Med [Internet]. 2014 [cited 2017 Mar 13];(1):1-4. Available from: https://www. ncbi.nlm.nih.gov/pmc/articles/PMC4045463/ pdf/ISRN.PREVENTIVE.MEDICINE2014-608927. pdf

16. World Health Organization. WHO guidelines on hand hygiene in health care (advanced draft): global safety challenge 2005-2006: clean care is safer care. Geneva: WHO; 2006.

17. Kampf G, Ruselack S, Eggerstedt S, Nowak N, Bashir M. Less and less-influence of volume on hand coverage and bactericidal efficacy in hand disinfection. BMC Infect Dis [Internet]. 2013 [cited 2017 Mar 13];13(1):472. Available from: https://bmcinfectdis.biomedcentral.com/ articles/10.1186/1471-2334-13-472
18. Herbert VG, Schlumm P, Kessler HH, Frings A. Knowledge of and adherence to hygiene guidelines among medical students in Austria. Interdiscip Perspect Infect Dis [Internet]. 2013 [cited 2017 Mar 13]; (1):1-6. Available from: https://www. hindawi.com/journals/ipid/2013/802930/

19. Stone SP, Fuller C, Savage J, Cookson B, Hayward A, Cooper B, et al. Evaluation of the national Cleanyourhands campaign to reduce Staphylococcus aureus bacteraemia and Clostridium difficile infection in hospitals in England and Wales by improved hand hygiene: four year, prospective, ecological, interrupted time series study. BMJ [Internet]. 2012 [cited 2017 Mar 13]; 344:3005. Available from: http://www.bmj. com/content/344/bmj.e3005

20. Pincock T, Bernstein P, Warthman S, Holst E. Bundling hand hygiene interventions and measurement to decrease health care-associated infections. Am J Infec Control. 2012; 40(4):18-27. 